\section{JURNAL PELITA PENDIDIKAN \\ Volume 8 Nomor 4 (2020), 215 - 223 \\ Jurnal Pelita Pendidikan}

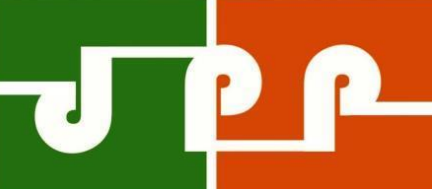

Journal of Biology Education

https://jurnal.unimed.ac.id/2012/index.php/pelita/index

eISSN: 2502-3217 pISSN: 2338-3003

\title{
PENERAPAN PENDEKATAN SAINTIFIK (SCIENTIFIC APPROACH) DALAM PEMBELAJARAN BIOLOGI SMA
}

\author{
As Tsaniyah Putri 'Aisyiyah, Amrizal \\ Pendidikan Biologi, Fakultas Matematika dan Imlu Pengetahuan Alam, Universitas Negeri Medan, Jl. Willem \\ Iskandar, Pasar V Medan Estate, 20221 \\ *Korespondensi Author: astsaniyahputri1997@gmail.com
}

\section{INFOARTIKEL}

\section{Riwayat artikel:}

Diterima 15 November

2020

Revisi 1 Desember 2020

Dipublikasikan 28

Desember 2020

Kata kunci:

aktivitas siswa, pembelajaran saintifik, pendekatan saintifik

\section{ABSTRAK}

Kurikulum 2013 menekankan pada peningkatan dan keseimbangan soft skills dan hard skills yang meliputi aspek kompetensi sikap, pengetahuan, dan keterampilan. Pembaharuan proses pembelajaran Kurikulum 2013 terletak pada pembelajaran yang menekankan pada dimensi pedagogik modern, yaitu menggunakan pendekatan saintifik (scientific approach). Pendekatan saintifik merupakan bagian inti dari kegiatan pembelajaran berbasis kontekstual. Penelitian ini bertujuan untuk mengetahui pelaksanaan pembelajaran biologi berbasis pendekatan saintifik (scientific approach), aktivitas siswa dalam penerapan pendekatan saintifik (scientific approach), dan stategi yang digunakan untuk mengatasi kendala pada penerapan pendekatan saintifik (scientific approach) dalam pembelajaran biologi di SMA Negeri 1 Binjai Kabupaten Langkat T.P.2019/2020. Desain penelitian yang digunakan yaitu deskriptif kuantitatif. Sampel yang diambil berjumlah 2 orang guru biologi dan 103 orang siswa. Teknik pengumpulan data menggunakan lembar observasi, angket siswa, dan pedoman wawancara. Hasil analisis menunjukkan bahwa pelaksanaan pembelajaran dengan pandekatan saintifik mendapat skor $77,60 \%$ dengan interpretasi cukup. Tahapan belajar saintifik yang dominan yaitu menanya, dan tahapan belajar saintifik yang menjadi masalah dalam pembelajaran yaitu mengasosiasi, dan mengomunikasikan.

\section{ABSTRACT}

The 2013 Curriculum emphasizes the improvement and balance of soft skills and hard skills which include aspects of competence in attitudes, knowledge and skills. The renewal of the 2013 Curriculum learning process lies in learning that emphasizes modern pedagogical dimensions, that is scientific approach. The scientific approach is a core part of contextual-based learning activities. This study aims to determine the implementation of biological learning based on scientific approach, the dominant activity student in the application of scientific approach, and the strategy that used to fixed the problem of the implementation of scientific approach in biology learning in SMA Negeri 1 Binjai Kabupaten Langkat T.P.2019 / 2020. The research design used is quantitative descriptive. The samples were 2 biology teachers and 103 students. Data collection techniques using, observation sheets, student questionnaires, and interview guidelines. The result of the analysis shows that the implementation of learning with scientific approach get score $77,60 \%$ which it is sufficiently. The dominant scientific learning stage is questioning, and the scientific learning stage which is a problem in learning that is associating, and communicating.

Copyright (C) 2019 Universitas Negeri Medan. Artikel Open Access dibawah lisensi CC-BY-4.0 (https://creativecommons.org/licenses/by/4.0) 


\section{How to Cite:}

Aisyiyah, A.P., \& Amrizal. (2020). Penerapan Pendekatan Saintifik Dalam Pembelajaran Biologi . Jurnal Pelita Pendidikan, $8(4), 215-223$

\section{PENDAHULUAN}

Kurikulum 2013 menekankan pada peningkatan dan keseimbangan soft skills dan hard skills yang meliputi aspek kompetensi sikap, pengetahuan, dan keterampilan. Pembaharuan proses pembelajaran Kurikulum 2013 terletak pada pembelajaran yang menekankan pada dimensi pedagogik modern, yaitu menggunakan pendekatan saintifik (scientific approach)(Musdar, 2017). Pemberlakuan kurikulum 2013 ditujukan untuk menjawab tantangan zaan terhadap pendidikan yakni untuk menghaisilkan lulusan yang kompetitif, inovatif, kreatif, kolaboratif, dan berkatakter (Widyasmoro, 2015). Langkah-langkah pendekatan saintifik dalam proses pembelajaran meliputi menggali informasi melalui pengamatan, bertanya, percobaan, kemudian mengolah data atau informasi, menyajikan data atau informasi, dilanjutkan dengan menganalisis, menalar, kemudian menyimpulkan, dan mencipta. Pendekatan saintifik (scientific approach) dapat mengembangkan kemampuan berfikir peserta didik (Musdar, 2017).

Pendekatan saintifik merupakan bagian inti dari kegiatan pembelajaran berbasis kontekstual. Pengetahuan dan keterampilan yang diperoleh siswa diharapkan bukan hasil mengingat seperangkat fakta tetapi merupakan hasil menemukan sendiri konsep-konsep yang ada, ditemukan sendiri oleh, bukan menurut buku (Irwandi, 2012). Dalam pembelajaran sains, siswa berperan seolah-olah sebagai ilmuwan, menggunakan metode ilmiah untuk mencari jawaban terhadap suatu permasalahan yang sedang dipelajari, sehingga siswa dilatih untuk memecahkan suatu masalah (Iskandar, 2014).

Untuk hasil belajar biologi kelas pembelajaran pendekatan saintifik (scientific approach) siswa memiliki nilai rata-rata 69,43 berkategori cukup. Adapun untuk kelas model pembelajaran langsung nilai hasil belajar siswa rata-rata 51,48 dengan kategori rendah (Marjan, 2014). Lalu penerapan pendekatan ini berpengaruh positif terhadap hasil belajar kognitif, afektif dan psikomotorik serta telah mencapai ketuntasan klasikal yang diterapkan, yakni lebih dari $85 \%$ dari seluruh siswa yang mengikuti pelajaran (Machin, 2014). Rahmatika (2017) juga menuliskan bahwa pelaksanaan pembelajaran dengan pendekatan saintifik (scientific approach) adalah sebesar $80 \%$ dengan interpretasi cukup terlaksana di SMA Negeri 1 Binjai. Lebih lanjut Siregar (2018) juga mengatakan bahwa tingkat ketercapaian perencanaan pembelajaran Kurikulum 2013 dengan pendekatan saintifik (scientific approach) adalah $79.30 \%$ sehingga termasuk ke dalam kategori cukup baik.

Dari hasil observasi yang dilakukan di SMA Negeri 1 Binjai Kabupaten Langkat, penerapan pendekatan saintifik (scientific approach) sudah terlaksana tetapi belum optimal. Dalam wawancara dua guru biologi yang dilakukan, guru pertama mengatakan bahwa suksesnya penerapan pendekatan saintifik (scientificapproach) berhubungan dengan guru dan siswa. Ketika guru sudah melakukan pendekatan saintifik (scientific approach), minat siswa yang menjadi kendala. Dalam kegiatan 5M, kegiatan mengumpulkan data dan mengasosiasikan menjadi hal yang kurang dalam siswa. Guru kedua juga mengatakan yang serupa, menurutnya hal ini sangat berkaitan dengan minat motivasi siswa dan metode pembelajaran yang digunakan. Di SMA Negeri 1 Binjai Kabupaten Langkat laboratorium biologi tidaklah memadai, sehingga guru lebih sering menggunakan metode ceramah dan diskusi dalam proses pembelajaran.

Penelitian ini bertujuan untuk mengetahui penerapan pendekatan saintifik (scientific approach) yang dilaksanakan selama pembelajaran di kelas, mengetahui respon aktivitas siswa terhadap pembelajaran biologi dengan pendekatan saintifik(scientific approach) dan mengetahui strategi yang digunakan guru untuk mengatasi kendala yang dihadapi dalam mengimplementasikan pembelajaran biologi dengan pendekatan saintifik(scientific approach)di SMA Negeri 1 Binjai Kabupaten Langkat.

\section{METODE PENELITIAN}

Penelitian dilaksanakan di SMA Negeri 1 Binjai Kabupaten Langkat yang beralamat di Jl. Yos 
Sudarso Suka Makmur, Sukamakmur, Kec. Binjai, Kabupaten Langkat Prov. Sumatera Utara. Waktu penelitian dimulai pada bulan September 2019 sebanyak 2 kali pertemuan. Penelitian dilaksanakan di kelas XI IPA.Sampel penelitian adalah 2 orang guru biologi dan 103 orang siswa yang tersebar dalam tiga kelas (IPA 1, IPA 2, IPA 5). Teknik pengambilan sampelnya menggunakan random sample.

Jenis penelitian ini adalah kuantitatif deskriptif, sehingga penelitian menggunakan metode survei dengan mengumpulkan data sebanyak-banyaknya yang mendeskripsikan suatu peristiwa berdasarkan realitas. Teknik pengumpulan data dilakukan dengan menggunakan observasi, angket, dan wawancara.
Lembar observasi pembelajaran saintifik dianalisis secara deskriptif kuantitatif dengan menggunakan skala likert. Lembar angket juga dianalisis dengan menggunakan skala likert, dan wawancara dianalisis secara deskriptif.

\section{HASIL DAN PEMBAHASAN}

Hasil proses pembelajaran biologi diperoleh dengan menggunakan lembar observasi dan hasil angket. Hasilnya kemudian dihitung dengan menggunakan acuan skala likert lalu dianalisis secara deskriptif kuantitatif. Hasil dari observasi dan hasil angket siswa tersebut dirata-ratakan sehingga diperoleh nilai dari proses pembelajaran biologi di SMA Negeri 1 Binjai Kabupaten Langkat.

Tabel 1. Hasil Proses Pembelajaran Guru Biologi di SMA Negeri 1 Binjai Kabupaten Langkat

\begin{tabular}{cccccc}
\hline \multirow{2}{*}{ Aktivitas } & \multicolumn{3}{c}{ Rata-rata } & \multirow{2}{*}{ Rata-rata } & \multirow{2}{*}{ Kategori } \\
\cline { 2 - 4 } & XI IPA 1 & XI IPA 2 & XI IPA 5 & & Kurang \\
Pendahuluan & 53,34 & 75,63 & 69,84 & 66,27 & Baik \\
Inti & 84,34 & 83,8 & 84,76 & 84,30 & Kurang \\
Penutup & 69,53 & 67,93 & 67,15 & 68,20 & \\
\hline
\end{tabular}

Tabel 1 adalah hasil dari seluruh aktivitaspembelajaran dari kelas XI IPA 1, XI IPA 2, dan XI IPA 5 yangmerupakan perwakilan dari seluruh kelas XI IPA yang dibawa oleh 2 guru biologi. Dari seluruh hasil rata-rata berdasarkan hasil observasi dan angket didapat bahwa kegiatan pendahuluan memiliki skor $66,27 \%$ dengan kategori cukup, kegiatan inti $84,30 \%$ dengan kategori baikdan kegiatan penutup 68,20 \% dengan kategori kurang.

Kegiatan pendahuluan dimulai dengan membuka pelajaran.Membuka pelajaran adalah suatu usaha yang dilakukan guru dalam kegiatan pembelajaran untuk menciptakan prakondisi bagi siswa agar mental maupun perhatian terpusat pada hal-hal yang akan dipelajari sehingga akan mudah mencapai kompetensi yang diharapkan(Sanjaya, 2011). Ada beberapa poin yang tidak terlaksana pada proses pembukaan, seperti tidak mendemonstrasikan sesuatu yang terkait dengan materi yang akan dipelajari dan terkadang di beberapa pertemuan penyampaian tujuan tidak dilakukan. Padahal menurut Sanjaya (2011), memperjelas pemahaman siswa tentang tujuan pembelajaran dapat menumbuhkan minat siswa untuk belajar yang pada gilirannya dapat meningkatkan motivasi belajar siswa.

Kegiatan inti pembelajaran antara lain mencakup penyampaian informasi, membahas materi standard untuk membentuk kompetensi dan karakter peserta didik, serta melakukan tukar pengalaman dan pendapat dalam membahas materi standard atau memecahkan masalah yang dihadapi bersama (Mulyasa, 2013). Nilai dari proses pendekatan saintifik (Tabel 2) dihitung berdasarkan hasil angket siswa dengan menggunakan skala likert.

Dari seluruh aktivitas penerapan pendekatan saintifik (scientific approach) dalam pembelajaran biologi di SMA Negeri 1 Binjai Kabupaten Langkat, didapat bahwa menanya adalah kegiatan yang paling dominan dengan persentase $24 \%$. serta aktivitas penerapan Scientific Approach dalam pembelajaran biologi yang terendah adalah mengomunikasikan dengan persentase $17 \%$. Lalu apabila kita rata-ratakan secara keseluruhan, hasil penerapan Scientific Approach dalam pembelajaran biologi terfokus pada tahapan $5 \mathrm{M}$ di SMA Negeri 1 Binjai Langkat terlaksana dalam kategori cukup dengan skor 77,60 \%. 
Tabel 2. Hasil Pendekatan Saintifik pada Pelajaran Biologi di SMA Negeri 1 Binjai Kabupaten Langkat

\begin{tabular}{lccccc}
\hline \multirow{2}{*}{ Pendekatan Saintifik } & \multicolumn{3}{c}{ Rata-rata } & \multirow{2}{*}{ Rata-rata } & Kategori \\
\cline { 2 - 4 } & XI IPA 1 & XI IPA 2 & XI IPA 5 & & \\
\hline Mengamati & 84,57 & 85,15 & 87,43 & 85,72 & Baik \\
Menanya & 93,93 & 93,18 & 96,43 & 94,51 & Amat Baik \\
Mengumpulkan Data & 77,15 & 74,25 & 65 & 72,13 & Cukup \\
Menginformasikan & 68,43 & 67,12 & 68,15 & 67,90 & Kurang \\
Mengomunikasikan & 67 & 61,97 & 74,19 & 67,72 & Kurang \\
\hline
\end{tabular}

Proses pelaksanaan pendekatan saintifik (scientific approach)yang diamati selama 2 hari berbeda. Pada hari pertama guru hanya memberikan metode ceramah, sehingga kegiatan mengasosiaikan dan mengkomunikasikan tidak tampak saat pembelajaran. Sementara pada pertemua kedua, proses pendekatan saintifik (scientific approach)sudah mulai terlihat dengan jelas.

Berdasarkan hasil observasi, kegiatan mengamati ini terlihat pada saat siswa mendengar, menyimak, dan melihat kelompok lain melakukan presentasi. Kelompok yang presentasi menampilan gambar, tulisan, dan juga video tentang apa itu jaringan meristem dan jaringan parenkim. Hal yang serupa juga dilakukan oleh Nuri (2018), dalam kegiatan mengamati guru memfasilitasi siswa untuk mengamati sumber belajar berupa buku dengan membaca materi, menayangkan gambar/video, dan menginstruksikan siswa untuk mendengarkan penjelasan dari guru dan presentasi kelompok lain.

Sesuai dengan Permendikbud Nomor 81 A Tahun 2013, tahapan 5M dalam kegiatan pendekatan saintifik adalah kegiatan siswa. Sehingga kegiatan menanya memberikan posisi kepada siswa sebagai subjek dalam pengajuan pertanyaan. Tahapan menanya adalah yang mendapat skor yang paling tinggi, yaitu 94,51\%. Hal ini memang dapat dilihat dari antusias dan jenis pertanyaan yang siswa berikan pada guru atau pada siswa lain sejak awal permbelajaran. Walaupun harus masih distimulus oleh guru, kualitas pertanyaan siswa sangatlah bagus sehingga siswa lain termotivasi untuk memberikan pertanyaan juga.

Dalam kegiatan mengumpulkan data, siswa menggunakan buku teks, internet, dan buku pegangan lain. Beberapa pertanyaan yang tidak bisa dijawab siswa, dibantu oleh guru. Berdasarkan
Permendikbud Nomor 81 A Tahun 2013 menyatakan bahwa kegiatan mengumpulkan data siswa dapat melaksanakan penyelidikan, percobaan, membaca sumber lain, mengamati objek atau kejadian, aktivitas, serta wawancara untuk mendapatkan informasi.

Dalam kegiatan mengasosiasikan, guru memberikan kesempatan kepada siswa untuk mencoba mengeksplor kemampuan mereka dalam menjawab pertanyaan-pertanyaan yang diajukan temannya.Pada saat ini, hubungan komunikasi antar siswa untuk analisa data terlihat baik, berbeda saat pertemuan pertama yang kebanyakan siswa bekerja secara mandiri.Kegiatan mengasosiasikan yang diteliti oleh Najakh (2018) dilakukan dengan mengerjakan soal-soal yang ada di buku teks maupun soal yang telah disediakan oleh guru yang dikerjakan 36 secara berkelompok maupun secara individu. Siswa diperbolehkan mengakses informasi tambahan dari internet maupun buku tambahan, segala informasi yang telah diperoleh dari tahapan mengumpulkan data. Sementara kegiatan mengasosiasikan yang diteliti oleh Nuri (2018) dilakukan dengan menarik kesimpuan secara bersama-sama.

Berdasarkan Permendikbud Nomor 81 A Tahun 2013, kegiatan mengomunikasikan dapat dilaksanakan dengan cara menyampaikan hasil pengamatan, kesimpulan berdasarkan hasil analisis baik secara lisan, tertulis, maupun media. Berdasarkan hasil observasi dan angket dari siswa didapat bahwa kegiatan mengomunikasikan adalah yang mendapat nilai terendah kedua. Dalam penelitian yang dilakukan oleh Najakh (2018) siswa memiliki motivasi yang rendah untuk mengemukakan pendapat atau hasil olah pikir mereka mengenai materi yang diajarkan. Siswa terpaku pada informasi yang terdapat pada buku teks pegangan yang diberikan dari sekolah. Guru lebih mendominasi untuk lebih memberikan 
penjelasan dan lebih dominan mengimbau siswa untuk membuat ringkasan materi dari buku teks pegangan yang diberikan dari sekolah tersebut.Pada saat observasi ketika mengomunikasikan dilakukan dengan kegiatan presentasi dan membuat kesimpulan. Hal yang sama juga didapat oleh Nuri (2018), dalam kegiatan mengomunikasikan guru meminta siswa untuk membuat laporan tulis sederhana dan memberi kesempatan kepada siswa untuk melakukan kegiatan mengomunikasikan dengan mempresentasikan hasil pengamatan.

Kegiatan menutup mendapat skor 68,20 \% dengan kategori kurang. Berdasarkan hasil diskusi dengan observer, hal ini dapat diakibatkan oleh alokasi waktu yang digunakan tidak mencakup untuk menyampaikan seluruh materi pelajaran dan kegiatan pembelajaran.Kasus ini mirip dengan apa yang ditulikan oleh Suharno (2014) dalam peneitiannya, penutup pembelajaran tidak melibatkan siswa dalam membuat kesimpulan. Guru nampaknya juga lupa tidak memberikan penguatan berupa pertanyaan ataupun tugas untuk persiapan pembelajaran berikutnya. Ada kesan tergesa-gesa karena kehabisan waktu akibat ceramah yang begitu dominan.vMenurut Sanjaya (2011) menutup pelajaran dapat diartikan sebagai kegiatan yang dilakukan guru untuk mengakhiri pelajaran dengan maksud untuk memberikan gambaran menyeluruh tentang apa yang telah dipelajari siswa serta keterkaitannya dengan pengalaman sebelumnya, mengetahui tingkat keberhasilan siswa, serta keberhasilan guru dalam proses pembelajaran. Sementara Rahmatika (2012) mengatakan kegiatan akhir dalam pembelajaran tidak hanya diartikan sebagai kegiatan untuk menutup pelajaran, tetapi juga sebagai kegiatan penilaian hasil belajar siswa dan kegiatan tindak lanjut.

Ada beberapa kendala aktivitas siswa dalam melaksanakan pembelajaran pendekatan saintifik (scientific approach) dilihat berdasarkan observasi dan angket siswa. Kemudian strategi dalam mengatasi kendala tersebut diperoleh dari hasil wawancara guru disertai diskusi dengan peneliti.

Tabel 3.Kendala aktivitas siswa dalam pelaksanaan pendekatan saintifik (scientific approach)

No

\section{Kendala aktivitas siswa dalam Pelaksanaan Penerapan Scientific Approach}

1 Mengamati. Dalam melakukan pengamatan, siswa hanya mengandalkan buku teks dan gambar yang disediakan guru. Alat bantu dalam pengamatan tidak dilakukan dan siswa masih harus diberi motivasi dan stimulus dalam kegiatan pengamatan.

2 Menanya. Siswa hanya aktif bertanya ketika guru memberikan contoh. Sedangkan jika secara mandiri, hanya sebatas beberapa siswa yang mau bertanya, dan pertanyaan yang diajukan sebatas beberapa pertanyaan yang ada pada buku paket.

3 Mengumpulkan data. Siswa hanya menggunakan buku paket dalam mengumpulkan data. Dan akan menambah sumber dari internet jika tugas dikerjakan di rumah. Sementara jika menggunakan buku pegangan lain, hanya beberapa siswa yang menggunakannya.

4 Mengasosiasikan. Siswa sangat jarang melakukan analisis dari diskusi yang dilakukan, dan tidak mendiskusikan data hasil temuan dengan teman sekelompoknya.

$5 \quad$ Mengomunikasikan. Siswa tidak menyajikan data dalam bentuk bagan, diagram atau grafik.

Dalam kegiatan mengamati karena biologi merupakan mata pelajaran yang mempelajari tentang makhluk hidup dan alam sekitar sehingga sangat tepat jika melaksanakan kegiatan pembelajaran di luar kelas ataupun praktikum. Sesuai dengan apa yang dikatakan Afcarino (2008), belajar biologi bukan hanya berhadapan dengan teori dan konsep saja, melainkan harus melakukan sesuatu, mengetahui, dan memecahkan masalah yang berkaitan dengan pembelajaran biologi. Akan tetapi, ruang praktikum tidak memadai di sekolah jadi guru sangat jarang untuk melakukan praktikum. Sama halnya dengan apa yang diteliti oleh Subarnia (2014) fungsi laboratorium sebagai pelengkap menyebabkan fasilitasnya kurang mendapat perhatian, bahkan ruangannya pun dipergunakan sebagai ruang kelas atau ruang guru. Sebenarnya untuk mengatasi kendala ini bisa dilakukan dengan membawa siswa belajar di luar kelas. Akan tetapi, ini juga akan berhubungan 
dengan mata pelajaran yang akan diajarkan. Jika ia hanya berupa sel dan jaringan, maka akan sulit untuk membawa peserta didik ke luar lapangan, dan akan lebih akurat jika melakukan praktikum dengan menggunakan mikroskop. Materi biologi tidak hanya berhubungan dengan fakta-fakta ilmiah tentang fenomena alam yang konkret, tetapi juga berkaitan dengan hal-hal atau objekobjek yang abstrak. Dengan demikian untuk merancang pembelajaran biologi diperlukan berbagai alat dukung, seperti: penggunaan media pembelajaran, sarana laboratorium dan lainnya (Rustaman, 2011; Sudarisman, 2015). Siswa aktif berpendapat dengan gambar yang ditampilkan oleh guru (Wina, 2017). Purwanti (2010) juga menuliskan penggunaan media konkret dapat meningkatkan aktivitas belajar. Selain meningkatkan aktivitas siswa, motivasi belajar siswa juga dapat ditingkatkan melalui media pembelajaran sesuai dengan hasil penelitian Kartikasari (2016).

Setelah kegiatan mengamati adalah kegiatan bertanya. Siswa lebih aktif jika guru memulai pelajaran dengan memberikan contoh dalam kehidupan nyata. Frekuensi siswa yang bertanya di awal pelajaran dengan memberikan contoh dan setelah melakukan pengamatan menggunakan gambar sangat berbeda. Gambar yang ditampilkan memanglah menarik, akan tetapi dengan memberikan contoh siswa langsung merasakannya dalam kehidupan nyata. Sehingga jalan alternatif yang diberikan melalui kegiatan bertanya adalah dengan membawa hal-hal yang dialami siswa ke dalam pelajaran, maka siswa akan memiliki rasa ingin tahu yang tinggi sehingga peran siswa untuk aktif mengikuti metode pembelajaran yang dilaksanakan guru dapat meningkat. Pengkaitan isi pelajaran dengan lingkungan sekitar akan membuat pelajaran yang didapat di kelas bermanfaat dalam kehidupan sehari-hari. Menurut Yani dan Ruhimat (2018) untuk membuat pertanyaan - pertanyaan dapat disusun dengan cara berdiskusi. Setelah pertanyaan terkumpul, salah seorang peserta didik membacakannya di depan kelas dan guru memilih beberapa pertanyaan yang dianggap rasional, dapat dijawab dengan data atau informasi yang tersedia, dan terjangkau oleh waktu belajar.
Dalam kegiatan mengumpulkan data siswa hanya menggunakan sumber buku pelajaran yang diberikan, dan akan menambah sumber belajar dari internet jika tugas yang diberikan dibawa pulang untuk dikerjakan di rumah. Strategi yang dapat dilakukan adalah dengan menambahkan minat belajar dan motivasi siswa. Terkadang guru sudah melaksanakan pendekatan saintifik akan tetapi terkendala karena minat siswa yang rendah. Siswa yang tidak aktif dalam proses pembelajaran dapat diatasi dengan penggunaan media pembelajaran.

Dalam mengasosiakan, siswa sangat jarang melakukan analisis dari diskusi yang dilakukan, dan tidak mendiskusikan data hasil temuan dengan teman sekelompoknya. Menurut guru, hal ini juga berkaitan dengan minat dan motivasi belajar siswa. Upaya alternative yang dapat dilakukan untuk mengatasi kendala ini adalah dengan mengubah skenario model pembelajaran yang telah direncanakan disesuaikan dengan situasi dan kondisi yang sedang terjadi di kelas atau lingkungan sekolah. Model-model pembelajaran tersebut dapat berupa modep pembelajaran yang inovatif yang proses pembelajarannya berpusat pada siswa (student centered), antara lain model pembelajaran kooperatif, model pembelajaran berbasis masalah (problem based learning), model pembelajaran kontekstual, model siklus belajar, model pembelajaran inkuiri, dan pembelajaran masalah (problem solving). Menurut Sani (2014) upaya untuk melatih siswa dalam melakukan penalaran dapat dilakukan dengan meminta siswa untuk mengalisis data yang telah diperoleh dehingga mereka dapat menemukan hubungan antar variabel, atau dapat menjelaskan tentang data berdasarkan teori yang ada, menguji hipotesis yang telah diajukan, dan membuat kesimpulan. Dalam penelitian yang dilakukan oleh Wina (2017), kegiatan menalar yang dilakukan siswa berbentuk ringkasan, pertanyaan, dan jawaban. Siswa diberikan kesempatan untuk menalar informasi yang didapatkan dari kelompoknya.

Kegiatan yang terakhir adalah mengomunikasikan.Yang menjadi kendala adalah siswa tidak menyajikan data dalam bentuk bagan, diagram atau grafik. Dalam wawancara guru, dikatakan bahwa seluruh rangkaian $5 \mathrm{M}$ saling 
berhubungan satu sama lain. Keberhasilan tahap akhir sangat bergantung dengan kegiatan sebelumnya. Jika siswa belum mampu menyajikan data dalam bentuk bagan, diagram atau grafik maka hal yang perlu diperbaiki adalah kegiatan mengamati, menanya, mengumpulkan data, dan mengasosiasikan. Minat siswa dan guru juga berpengaruh untuk meningkatkan daya analisa siswa. Untuk ini hal-hal yang disebutkanlah yang perlu diperbaiki. Karena kondisi pembelajaran yang diharapkan dari pendekatan saintifik adalah mendorong peserta didik dalam mencari tahu dari berbagai sumber melalui observasi, bukan hanya diberi tahu. Menurut Fauziah (2013) pendekatan saintifik mengajak siswa langsung menginverensi masalah yang ada dalam bentuk rumusan masalah dan hipotesis. Dalam pelaksanaannya, siswa akan memperoleh kesempatan untuk melakukan penyelidikan dan inkuiri serta mengembangkan dan menyajian hasil karya.

Penelitian yang dilakukan oleh Aryani (2012), ada beberapa hambatan yang dialami oleh guru dalam pelaksanaan pendekatan saintifik (scientific approach) antara lain: (1) pada kegiatan menanya sulit menarik minat siswa untuk bertanya maupun memberikan pendapat mereka dalam pembelajaran, (2) kurangnya pengelolaan waktu oleh guru, (3) rumitnya persiapan yang harus dilakukan oleh guru, (4) guru kurang mampu mengelola kelas sehingga kegiatan belajar menjadi tidak kondusif. Untuk itu, agar pembelajaran saintifik berjalan dengan baik. Siswa dan guru harus saling berkerja sama dan berkoordinasi satu sama lain.

Dengan pembelajaran saintifik, siswa diharapkan memiliki kemandirian dalam belajar. Pelajaran biologi sangat berkaitan dengan kehidupan sehari-hari sehingga siswa mampu merumuskan masalah dan melakukan langkahlangkah ilmiah untuk menemukan jawabannya. Peran guru juga sangat penting sebagai fasilitator dan yang akan membimbing siswa. Sehingga sumber belajar dan media pembelajaran sangat dibutuhkan. Diharapkan nantinya pembelajaran pendekatan saintifik (scientific approach) mampu mengembangkan sikap kognitif, afektif, dan psikomorotik siswa.

\section{KESIMPULAN}

Berdasarkan hasil penelitian yang diperoleh dari hasil analisis data dan tambahan wawancara guru biologi maka dapat disimpulkan bahwa penerapan scientific approach dalam pembelajaran biologi di kelas XI IPA SMA Negeri 1 Binjai Kabupaten Langkat dalam kegiatan pembelajaran secara keseluruhan, meliputi kegiatan awal, kegiatan inti, dan kegiatan penutup mendapat kategori cukup. Dari seluruh kegiatan aktivitas siswa dalam pendekatan saintifik kegiatan menanya adalah kegiatan yang paling dominan sementara kegiatan yang kurang diminati siswa adalah kegiatan mengasosiasikan. Adapun strategi yang bisa dilakukan untuk mengatasi kendala siswa dalam melakukan pendekatan saintifik adalah memberikan obyek pengamatan yang menarik perhatian untuk mengamati, memancing siswa untuk bertanya dengan memberikan contoh dalam kehidupan yang dialami siswa, penyediaan sumber belajar yang banyak untuk mengumpulkan data, penggunaan model dan metode pembelajaran yang menarik untuk mengasosiasikan, dan mengoptimalkan kegitan $5 \mathrm{M}$ agar hasil akhir dapat berjalan dengan baik. Penelitian ini diharapkan terus dikembangkan dengan melihat bagaimana penderapan pendekatan saintifik dapat mempengaruhi askep kognitif, afektif, dan psikomotorik siswa.

\section{UCAPAN TERIMAKASIH}

Ucapan terima kasih disampaikan kepada Guru dan Kepala Sekolah SMA Negeri 1 Binjai Kabupaten Langkat yang telah membantu dalam penelitian ini.

\section{DAFTAR PUSTAKA}

Afcarino, M., (2008), Penerapan Pembelajaran Berbasis Masalah untuk Meningkatkan Kemampuan Berfikir Siswa pada Mata Pelajaran Biologi, Jurnal Pendidikan Volume Inovatif, Vol 3, No 2: 65-68.

Aryani, M.F., (2014), Studi Kasus Penerapan Pendekatan Saintifik pada Guru-Guru di SMA N 1 Bawang, Economic Education Analysis Journal, Vol 3, No 3: 558-563.

Fauziah, R, A.G Abdullah, D.L Hakim, (2013), Pembelajaran Saintifik Elektronika Dasar Berorientasi Pembelajaran 
Berbasis Masalah, Jurnal Invorec, Vol 9, No 2: 165-178.

Irwandi, (2012), Pengaruh Pendekatan Kontekstual dalam Pembelajaran Biologi melalui Strategi Inkuiri dan Masyarakat Belajar pada Siswa dengan Kemampuan Awal Berbeda terhadap Hasil Belajar kognitif di SMA Negeri Kota Bengkulu. Jurnal Kependidikan Triadik, Vol 12, No 1: 33-41.

Iskandar, S.M., (2014), Pendekatan Keterampilan Metakognitif dalam Pembelajaran Sains di Kelas, ERUDIO, Vol 2, No 2: 14-20.

Kartikasari, G., (2016), Pengaruh Media Pembelajaran Berbasis Mulimedia terhadap Motivasi dan Hasil Belajar Materi Sistem Pencernaan Manusia Studi Eksperimen pada Siswa Kelas V MI Miftahul Huda Pandantoyo, Dinamika Penelitian, Vol 16, No 1: 5977

Machin, A., (2014), Implementasi Pendekatan Saintifik, Penanaman Karakter dan Konservasi pada Pembelajaran Materi Pertumbuhan. Jurnal Pendidikan IPA Indonesia, Vol 3, No 1: 28-35.

Marjan, J, I.B Putu Arnyana, I.G.A Nyoman Setiawan, (2014), Pengaruh Pembelajaran Pendekatan Saintifik terhadap Hasil Belajar Biologi dan Keterampilan Proses Sains Siswa MA Mu'allimat NW Pancor Jaringan pada tumbuhanong Kabupaten Lombok Timur Nusa Tenggara Barat, e-journal Program Pascasarjana Universitas Pendidikan Ganesha, Vol 4.

Mulyasa, H.E., 2013. Pengembangan dan Implementasi Kurikulum 2013, Rosdakarya. Bandung.

Musdar, M., (2017), Pemetaan Konsep Fisika Siswa Kelas XI pada Kurikulum 2013, Jurnal Pendidikan Fisika dan Keilmuan (JPFK), Vol 4, No 1: 36-41.

Najakh, S.H., (2018), Pemetaan Penerapan Scientific Approach dalam Pembelajaran Biologi di SMA Negeri 1 Batang Kuis T.P 2017/2018, Skripsi, Universitas Negeri Medan.

Nuri, A., (2018), Survei Pemetaan Proses Pembelajaran Biologi Berbasis Pendekatan Saintifik (Scientific Approach) di SMA Muhammadiyah 1 Medan Tahun Pembelajaran
2018/2019, Skripsi, Universitas Negeri Medan.

Purwanti, L., (2010), Peningkatan Aktivitas Pembelajaran IPA dengan Media Benda Konkret pada Siswa Kelas II SDN 01 Kaling tasikmadu Karanganyar Tahun 2009/2010, Skripsi, FKIP, Universitas Sebelas Maret, Surakarta.

Rahmatika, U., (2017), Pemetaan Pembelajaran Biologi Berbasis Scientific Approach di SMA Negeri 1 Binjai, Jurnal Pelita Pendidikan, Vol 6, No 1: 028-035.

Rustaman, N.Y., (2011), Pendidikan dan Penelitian Sains dalam Mengembangkan Keterampilan Berpikir Tingkat Tinggi untuk Pembangunan Karakter. Makalah Seminar Nasional VIII $P$. Biologi, FKIP UNS, Surakarta.

Sani, R.A., (2014), Pendekatan Saintifik Untuk Implementasi Kurikulum 2013, Bumi Aksara, Jakarta.

Sanjaya, W., (2011), Strategi Pembelajaran Berorientasi Standar Proses Pendidikan, Kencana, Jakarta.

Siregar, M, K., (2018), Implementasi Kurikulum 2013 dengan Pendekatan Saintifik (Scientific Approach) pada Mata Pelajaran Biologi. Jurnal Pelita Pendidikan, Vol 6, No 4: 238-246.

Subarnia IDP, P Artawan, S Wahyuni, (2014), Analisis Kebutuhan Tata Laksana Laboratorium IPA SMP di Kabupaten Buleleng, Jurnal Pendidikan Indonesia, Vol 3, No 2: 446-459.

Sudarisman, S., (2015), Memahami Hakikat dan Karakteristik Pembelajaran Biologi dalam Upaya Menjawab Tantangan Abad 21 serta Optimalisasi Implementasi Kurikulum 2013, Jurnal Florea, Vol 2, No 1: 29-35

Suharno, (2014), Implementasi Pembelajaran Berbasis Kurikulum 2013 pada Mata Pelajaran Biologi di SMA Negeri 1 Gondang Kabupaten Tulungagung,Jurnal Humanisty, Vol 10, No 1:147-157.

Widyasmoro, C., (2015), Identifikasi dan Analisis Hambatan Guru Biologi Kelas X dalam Implementasi Standar Proses dan Standar Penilaian Kurikulum 2013 di SMA Negeri Se Kabupatem Semarang, Skripsi, Universitas Negeri Semarang.

Wina, D.R, N Hindarto, A.P.B Prasetyo, (2017), Studi Kasus Pendekatan Saintifik 
dalam Pembelajaran IPA pada Kurikulum 2013 di SMP Negeri 5 Semarang, Journal of Innovative Science Education, Vol 6, No 1: 18-27

Yani, A, Ruhimat, M., (2018), Teori dan Implementasi Pembelajaran Saintifik Kurikulum 2013, PT. Refika Aditama, Bandung. 